\title{
A NEW SPECIES OF SALACIA (HIPPOCRATEACEAE) FROM SOUTH INDIA
}

\author{
P. S. Udayan ${ }^{1}$, Regy Yohannan ${ }^{2}$, M. S. Devipriya ${ }^{2}$, \\ V. DEVIPRIYA ${ }^{2} \& A \cdot K$. PRADEEP ${ }^{3}$
}

A new species from South India, Salacia agasthiamalana Udayan, Regy Yohannan \& Pradeep (Hippocrateaceae), is described from the Western Ghats of Thiruvananthapuram District, Kerala State. An illustration and data on habitat, distribution and phenology are provided.

Keywords. Hippocrateaceae, Kerala, Salacia, South India.

\section{INTRODUCTION}

The genus Salacia L. (Hippocrateaceae) consists of approximately 200 species distributed in tropical America, Africa and Asia (Mabberley, 2005). In India it is represented by 21 species, of which 15 species are known to occur in Peninsular India (Ramamurthy \& Naithani, 2000). Among them, eight species are recorded from Kerala (Sasidharan, 2004; Ramamurthy \& Venu, 2005; Nayar et al., 2006). During intensive botanical studies along the Western Ghats of Kerala State in South India we collected an interesting species of Salacia from Agasthiamala forest of Thiruvananthapuram District. Critical studies revealed it to be a new species and it is described here with an illustration.

\section{SPECIES DESCRIPTION}

Salacia agasthiamalana Udayan, Regy Yohannan \& Pradeep, sp. nov. Fig. 1.

Salaciae macrospermae Wight affinis, sed ab ea praesertim habitu fruticoso scandenti, ramulis denigrescentibus lenticellatis, foliis $5-6.5 \mathrm{~cm}$ longis ellipticis atrovirentibus coriaceis serrato-crenatis, petiolis 5-7 cm longis, cymis 2-8-floribus et fructibus laevigatis differt. - Type: India, Kerala, Thiruvananthapuram

\footnotetext{
${ }^{1}$ Department of Botany, Sree Krishna College, Ariyannur P.O., Guruvayur, Thrissur, Kerala 680102 , India. E-mail: psudayan@rediffmail.com

2 Department of Botany, Sree Narayana College, Kollam, Kerala, India.

${ }^{3}$ Department of Botany, Calicut University, Kerala 673 635, India.
} 


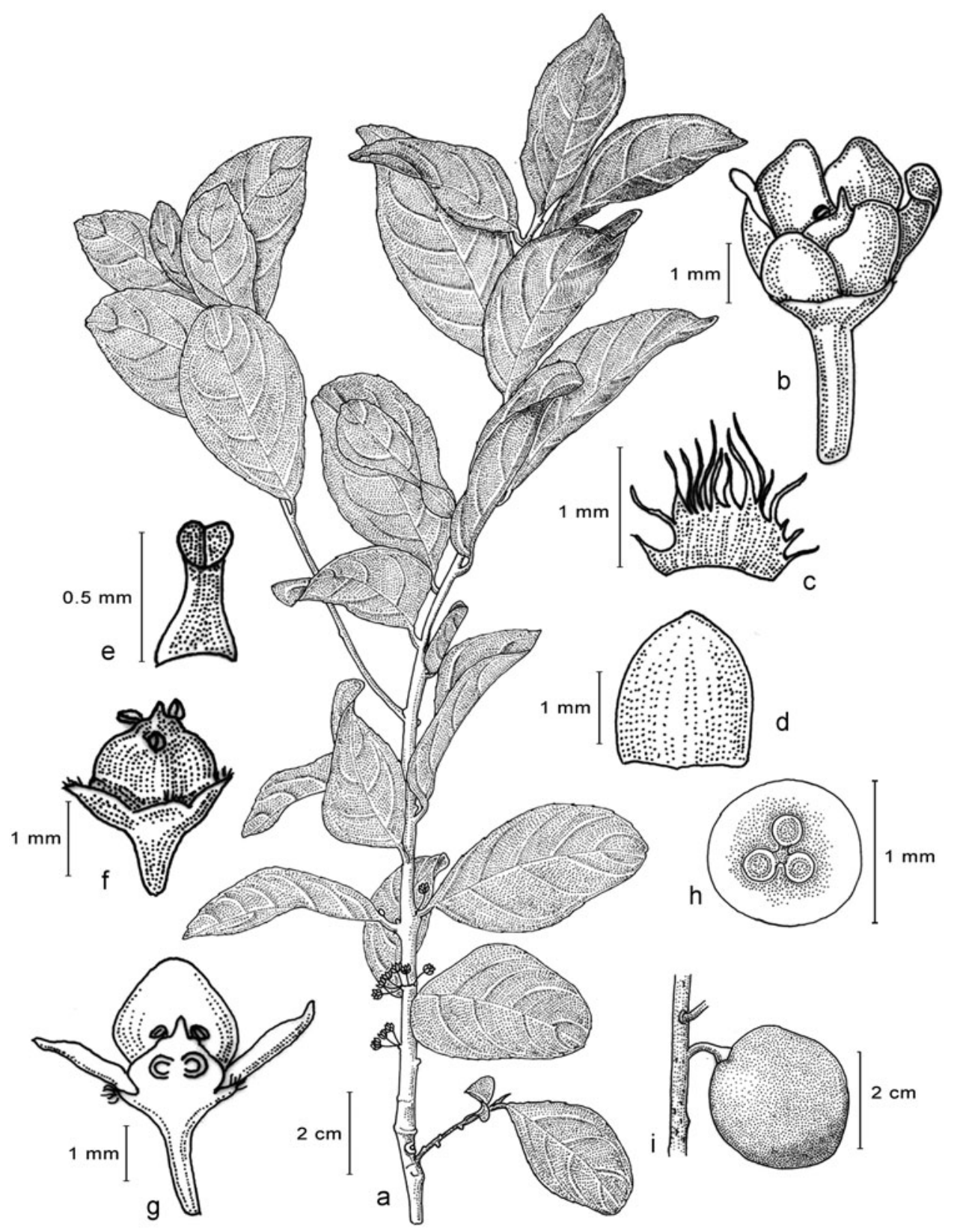

FIg. 1. Salacia agasthiamalana Udayan, Regy Yohannan \& Pradeep, sp. nov.: a, twig with flowers; b, single flower; c, sepal; d, petal; e, stamen; f, calyx and disk with androecium and gynoecium; g, longitudinal section of flower; h, cross-section of ovary; i, fruit. a from Udayan S006; b-h from Udayan S004; i from Udayan S008. Drawn by Umesh M. 
District, Agasthiamala, evergreen forest, 900-1000 m, 11 iv 2010 (fl), Udayan \& Regy Yohannan $\mathrm{S} 004$ (holo $\mathrm{MH}$; iso $\mathrm{K}, \mathrm{SKC}^{1}, \mathrm{SNCH}^{2}$ ).

Scandent bushy shrubs; branchlets lenticellate, blackish. Leaves elliptic, 5-6.5 $\times 2-$ $3.5 \mathrm{~cm}$, acute, acuminate or rounded-retuse at apex, acute or cuneate at base, coriaceous, margin serrate in young leaves but crenate in mature leaves, venation reticulodromous; petiole $0.5-0.7 \mathrm{~cm}$ long. Flowers $2-8$, cauliflorous umbelliform cyme in dense fascicles from axillary or extra-axillary branches; pedicel $0.4-0.6 \mathrm{~cm}$ long. Sepals 5, oblong, brown, c. $0.1 \mathrm{~cm}$ long, much shorter than the petals, margins fimbriate. Petals 5, elliptic, $0.2 \times 0.15 \mathrm{~cm}$, green with a tinge of yellow when young but orange tinged towards the upper margins in older flowers. Disk green when young but with a faint orange tinge towards the base at maturity, $0.05 \mathrm{~cm}$ high, $0.1 \mathrm{~cm}$ wide, conical, tapering to a short style. Anthers 3 , rarely 4 , discoid, creamywhite with a brown tinge; filament slightly tri-radiate, creamy-white when young but yellowish with an orange tinge later. Ovary superior, 3-loculed; ovules 1 in each locule; stigma simple umbonate, pale green. Berry globose, smooth, 4-6 cm across, orange-red. Seeds slightly plano-convex, 1.5-2 $\times 1-1.5 \mathrm{~cm}$.

Distribution. Salacia agasthiamalana is known from Pongalapara in the Agasthiamala region of the southern Western Ghats of Kerala. It is apparently endemic and very sparsely distributed on the slopes.

Habitat and ecology. This species occurs in evergreen grassland vegetation at an altitude of 900-1100 m. Flowering and fruiting: September and April; March and July.

Etymology. The species is named after the type locality, Agasthiamala Biosphere Reserve, one of the floristically rich regions of the southern Western Ghats.

Additional specimens examined. InDIA. Kerala, Thiruvananthapuram District, Agasthiamala, 950-1100 m, 4 v 2010, Udayan \& Regy Yohannan S006 (CALI, SNCH); ibid., 10 iii 2011, Udayan \& Regy Yohannan S008 (CAL, CALI, FRLH, MH).

This new species is most similar to Salacia macrosperma Wight in its cauliflorous many-flowered umbelliform cymes and globose orange-red berries but can be distinguished from it by its bushy scandent habit; blackish lenticellate branchlets; 5-6.5 cm long, dark green, elliptic, coriaceous, serrate-crenate leaves; short (5-7 mm) petioles; few-flowered (2-8) cymes and smooth berries.

The plant was found growing together with other rare and endemic species such as Actinodaphne campanulata Hook.f. (Lauraceae), Bentinckia condapanna Berry \& Roxb. (Arecaceae), Byrsophyllum tetrandrum (Bedd.) Hook.f. ex Bedd. (Rubiaceae), Eugenia indica (Wight) Chithra (Myrtaceae), Euphorbia santapaui A.N.Henry

\footnotetext{
1 Sree Krishna College (SKC), Guruvayur, Kerala, India.

2 Sree Narayana College (SNCH), Kollam, Kerala, India.
} 
(Euphorbiaceae), Hedyotis albonervia Bedd. (Rubiaceae), Microtropis ramiflora Wight (Celastraceae) and Polyscias acuminata (Wight) Seem. (Araliaceae).

\section{ACKNOWLEDGEMENTS}

The authors are grateful to Dr V. P. Prasad, IBLO, Royal Botanic Gardens, Kew, for comments on the identity of the species; Dr M. Sanjappa, Botanical Survey of India (BSI), Kolkatta, Dr G. V. S. Murthy, Botanical Survey of India (BSI), Coimbatore, and Dr N. Sasidharan, Kerala Forest Research Institute (KFRI), Thrissur for their help; Kerala State Council for Science, Technology \& Environment (KSCSTE), Thiruvananthapuram for financial support; Mr Umesh M., Project Fellow, Sree Narayana College, Kollam for the illustration; the authorities of Kerala State Forest Department for permission for field visits, and Mr Satheesh George, Arya Vaidya Sala, Kottakkal and Mr A. J. Robi, Project Fellow, KFRI, Thrissur for assistance in the field.

\section{REFERENCES}

Mabberley, D. J. (2005). The Plant-Book: A Portable Dictionary of the Vascular Plants. Cambridge, UK: Cambridge University Press.

Nayar, T. S., Rasiya Beegam, A., Mohanan, N. \& Rajkumar, G. (2006). Flowering Plants of Kerala. Palode, Thiruvananthapuram, Kerala: Tropical Botanical Garden Research Institute.

Ramamurthy, K. \& Naithani, B. D. (2000). In: Singh, N. P., Vohra, J. N., Hajra, P. K. \& Singh, D. K. (eds) Flora of India, vol. 5. Calcutta: Botanical Survey of India.

Ramamurthy, K. \& Venu, P. (2005). In: Daniel, P. (ed.) Flora of Kerala, vol. 1. Calcutta: Botanical Survey of India.

Sasidharan, N. (2004). Biodiversity Documentation for Kerala. Part 6. Flowering Plants. Peechi, Kerala: Kerala Forest Research Institute. 